\title{
Analisis Sikap Konsumen Pada Produk Kopi (Studi Kasus Pada Perusahaan Pdp Kahyangan Kabupaten Jember )
}

\section{Consumer Attitudes Analysis Of Coffee Attributes (Case Studies At Pdp Kahyangan Corporation, Kabupaten Jember)}

\author{
Naning Retnowati ${ }^{1)}$, Alwan Abdurahman ${ }^{2)}$ \\ Program Studi Manajemen Agribisnis Jurusan Manajemen Agribisnis Politeknik Negeri Jember \\ Jalan Mastrip Kotak Pos 164 Jember \\ 1) email: naninkretnowati83egmail.com \\ ${ }^{2)}$ email:alwanperpusegmail.com
}

\begin{abstract}
The purposes of this research are to determine : 1) attributes criteria that are considered by consumer in coffee buying process, 2) consumer attitudes toward coffee product attributes of PDP Kahyangan than its competitor (Kapal Api Special). The method of data analysis used in this research is the Fishbein Attitude Model. This research uses eight attributes of product, those are colour, aroma, flavour, acidity, viscosity, package, price, product availability, and product recognition. Based on this research flavour, aroma and accidity attribute are the most considered by consumer in coffee buying decision process and then followed by viscosity, product availability, colour, product recognition, package, and price. The total value of consumer attitudes toward both PDP Kahyangan and Kapal Api Special are positive, that is with the value of 138,53, it's fewer than Kapal Api Special $(\mathbf{1 6 2 , 8 5})$. Consumer attitude in flavour product attribute of PDP Kahyangan is better than Kapal Api Special, with the best value of 23,03 . It showed that consumer acceptance flavour product attribute of PDP Kahyangan is is better than Kapal Api Special.
\end{abstract}

Keywords : Coffee, Fishbein Attitude Model, Product Attributes

\section{PENDAhuluan}

\subsection{Latar Belakang}

Kopi merupakan salah satu bahan penyegar yang nilainya tidak hanya ditentukan oleh penampilannya secara fisik, akan tetapi lebih ditentukan oleh cita rasanya. Kopi disebut bahan penyegar karena kandungan senyawa kafein dalam kopi yang dapat memberikan efek kesegaran bagi yang mengkonsumsinya (Yusianto dan Mulato, 2007). Selain itu kopi juga disukai karena cita rasanya yang khas. Cita rasa kopi dipengaruhi oleh beberapa aspek diantaranya yang paling utama adalah bahan baku biji kopi yang digunakan (kandungan senyawa kimia pada kopi, jenis kopi, asal kopi) dan proses pengolahan yang dilakukan.
Saat ini permintaan konsumen lokal terhadap produk kopi semakin meningkat. Perkembangan konsumsi pada produk kopi perlu diperhatikan secara baik agar dapat dimanfaatkan secara maksimal untuk perkembangan pemasaran produk kopi.

Persaingan di dunia industri yang semakin ketat memaksa setiap perusahaan agar dapat menghasilkan produk dengan kualitas atau mutu terbaik. Maka dari itu kualitas produk menjadi salah satu faktor yang harus diperhatikan perusahaan dalam merebut pangsa pasar. Kualitas menjadi faktor dasar bagi konsumen dalam mengambil keputusan akan membeli suatu produk yang diinginkan atau justru sebaliknya. 
Naning Retnowati, Alwan Abdurahman. Analisis Sikap Konsumen Pada Produk Kopi (Studi Kasus

Pada Perusahaan Pdp Kahyangan Kabupaten Jember )

Perusahaan Daerah Perkebunan (PDP) Kabupaten Jember adalah Badan Usaha Milik Daerah (BUMD) Pemerintah Kabupaten Jember yang bergerak dibidang Perkebunan dan beroperasi sejak tahun 1969. Komoditas utama perusahaan ini adalah kopi dan karet dengan luas lahan perkebunan kurang lebih 4.278,2239 Ha. Pada tahun 2002 PDP Kabupaten Jember melakukan diversifikasi produk biji kopi Robusta menjadi kopi sangrai dan kopi bubuk dengan merek "PDP" untuk memenuhi kebutuhan masyarakat Jember. Pada tahun 2012 produk kopi bubuk merek "PDP" diubah menjadi “" Kahyangan".

Pada saat ini perusahaan dihadapkan oleh semakin beragamnya keinginan konsumen sehingga menjadi suatu keharusan bagi perusahaan untuk dapat memenuhi kebutuhan konsumen tersebut. PDP Kahyangan Jember harus memahami atribut-atribut apa saja yang mempengaruhi konsumen saat akan membeli produk kopi. PDP Kahyangan Jember selalu berusaha untuk mempertahankan mutu produk kopinya agar dapat memenuhi standar kualitas yang telah ditentukan oleh konsumen. Maka dari itu PDP Kahyangan Jember perlu mempelajari perilaku konsumen terhadap produk kopi agar dapat meningkatkan daya saing produknya.

Sikap konsumen merupakan salah satu komponen penting dalam perilaku pembelian. Menurut Fishbein dan Ajzen (dalam Kristianto, 2011), sikap merupakan presdisposisi (keadaan mudah terpengaruh) yang dipelajari untuk menanggapi secara konsisten terhadap suatu objek, baik dalam bentuk tanggapan positif maupun tanggapan negatif. Konsep sikap sangat berkaitan dengan konsep kepercayaan (belief) dan perilaku (behavioral).

Schifman dan Kanuk (2004) menyatakan bahwa sikap adalah ekspresi perasaan (innerfeeling), yang mencerminkan apakah seseorang senang atau tidak senang, suka atau tidak suka, dan setuju atau tidak setuju terhadap suatu objek. Objek yang dimaksud bisa berupa merek, layanan, pengecer, prilaku tertentu, dan lain-lain (Simamora, 2002). Sikap konsumen dapat digunakan sebagai sumber informasi untuk membantu perusahaan dalam mempersiapkan produk yang sesuai dan dapat diterima oleh konsumen ataupun pelanggan.

Metode yang digunakan dalam penelitian adalah Model Sikap Fishbein. Model sikap Fishbein menyatakan bahwa sikap seseorang konsumen terhadap suatu obyek akan ditentukan oleh sikapnya terhadap berbagai atribut yang dimiliki oleh suatu obyek tersebut.

\subsection{Perumusan Masalah}

Perumusan masalah yang dapat diidentifikasikan adalah :

a) Apakah kriteria atribut produk kopi yang diinginkan dan dibutuhkan oleh konsumen?

b) Bagaimanakah sikap konsumen terhadap atribut produk kopi bubuk Kahyangan dibandingkan produk kompetitor (Kapal Api Special)?

\subsection{Tujuan Penelitian}

Tujuan dari penelitian ini adalah:

a) Untuk mengetahui kriteria atribut produk kopi yang menjadi pertimbangan utama konsumen dalam pembelian produk.

b)Untuk mengetahui sikap konsumen terhadap produk kopi bubuk Kahyangan dibandingkan produk kompetitor (Kapal Api Special).

\subsection{Manfaat Penelitian}

a)Manfaat bagi produsen kopi (PDP

Kahyangan) antara lain adalah :

- Memberi informasi tentang macam atribut produk kopi yang menjadi pertimbangan utama konsumen dalam pembelian produk.

- Memberi informasi mengenai sikap konsumen terhadap atribut produk kopi.

- Informasi penilaian kepercayaan konsumen terhadap atribut produk kopi membantu produsen (PDP Kahyangan) dalam menyusun prioritas perbaikan proses produksi

b)Manfaat bagi konsumen adalah :

Kepuasan konsumen terhadap produk kopi dapat semakin meningkat karena produsen senantiasa berupaya untuk meningkatkan kualitas produk kopinya.

\section{METODOLOGI}

\subsection{Jenis Penelitian}

Jenis penelitian yang digunakan oleh penulis adalah penelitian survey yaitu pengumpulan informasi secara sistematik dari responden dengan maksud untuk memahami aspek perilaku dari populasi yang diteliti (Sekaran, 2000). Pendekatan penelitian yang dilakukan adalah menggunakan mix methods, dimana metode kuantitatif merupakan pendekatan utama penelitian dan metode kualitatif disertakan untuk melengkapi dan mempertajam pembahasan hasil penelitian.

\subsection{Waktu dan Tempat Penelitian}

Penelitian dilakukan pada bulan Agustus Desember 2014. Penelitian untuk memperoleh data primer dari responden konsumen akhir (end customer) akan dilakukan secara langsung di wilayah Kabupaten Jember. 


\subsection{Identifikasi Variabel}

Variabel yang menjadi perhatian pada penelitian ini adalah variabel bebas (independent) dan variabel tak bebas (dependent). Variabel bebas (independent) meliputi 4 P (Product, Price, Place dan Promotion). Variabel bebas berupa Produk (Warna, Aroma, Rasa, Keasaman, Kekentalan, dan Kemasan), Harga, Ketersediaan dan Informasi Produk. Variabel tak bebas (dependent) yaitu berupa sikap konsumen pada produk kopi.

\subsection{Pemilihan Responden}

Penelitian ini melibatkan responden konsumen. Responden responden konsumen yang dipilih adalah konsumen akhir (end customer) berjumlah 100 orang dengan kriteria seseorang yang pernah mengkonsumsi produk kopi bubuk Kahyangan dan Kapal Api Special .

\subsection{Metode Pengumpulan Data}

Data primer dikumpulkan dengan instrumen berupa kuesioner isian (angket) yang bersifat tertutup, dimana responden menjawab pertanyaan dengan memilih alternatif jawaban sesuai dengan pendapatnya (closed questioner). Kuesioner dikembangkan dari model Fishbein dan Ajzen (Dharmmesta, 1997). Semua variabel diukur dengan menggunakan Skala Likert (Skala $1-5)$.

\subsection{Uji Validitas dan Reliabilitas Instrumen}

Agar instrumen yang dipakai dalam penelitian ini dapat berfungsi sebagaimana yang diharapkan, maka instrumen tersebut perlu diuji validitas dan reliabilitasnya. Uji validitas dan reliabilitas dilakukan melalui uji statistik dengan menggunakan software SPSS 16.0.

2.7 Teknik Analisis Dengan Mode Multiatribut Fishbein

Model multiatribut Fishbein atau disebut dengan Attitude Toward Object Model. The attitude toward object model (Sumarwan, 2011), digunakan untuk mengukur sikap konsumen terhadap sebuah produk. Model multiatribut menekankan adanya salience of attributes. Salience artinya tingkat kepentingan yang diberikan konsumen kepada sebuah atribut. Model ini juga menggambarkan sikap konsumen terhadap suatu produk atau merek ditentukan dua hal, yaitu evaluasi pentingnya atribut dari produk tersebut (komponen $\mathrm{e}_{\mathrm{i}}$ ) dan kepercayaan terhadap atribut yang dimiliki produk (komponen $\mathrm{b}_{\mathrm{i}}$ ).

Formulasi matematis dari model sikap terhadap obyek, oleh Fishbein dapat dirumuskan sebagai berikut:

$$
\mathrm{A}_{0}=\sum_{\mathrm{i}=0}^{\mathrm{n}} \mathrm{b}_{\mathrm{i}} \mathrm{e}_{\mathrm{i}}
$$

dimana :

$\mathrm{A}_{0}=$ sikap terhadap obyek $\mathrm{O}$ (produk, merek, dan lan-lain)

$\mathrm{b}_{\mathrm{i}}=$ kepercayaan (believe) $\mathrm{I}$ tentang obyek $\mathrm{O}$, yaitu: probabilitas subyektif bahwa dihubungkan pada atribut I

$\mathrm{e}_{\mathrm{i}}=$ evaluasi (evaluation) dari atribut $\mathrm{I}$

$\mathrm{n} \quad=$ jumlah keyakinan

Berdasarkan uraian diatas, para konsumen akan memiliki sikap yang baik terhadap suatu merek tertentu, jika mereka menilai tingkatan atribut yang dimilikinya positif dan cukup memuaskan, dan sebaliknya akan memiliki sikap yang tidak baik terhadap merek tertentu, jika mereka merasakan bahwa atribut-atribut yang diinginkan tidak memuaskan atau terlalu banyak atribut yang negatif.

\section{HASIL DAN PEMBAHASAN}

\subsection{Uji Validitas dan Reliabilitas}

Pada penelitian ini dilakukan pengujian instrumen penelitian terlebih dahulu dengan menggunakan uji validitas dan uji reliabilitas. Hasil uji validitas pada evaluasi (evaluation) konsumen dan kepercayaan (believe) konsumen terhadap atribut produk kopi ditunjukkan pada Tabel 1.

Berdasarkan hasil uji validitas data, yang ditunjukkan pada Tabel 1 dapat diketahui bahwa tiap pertanyaan pada kuesioner penentuan evaluasi dan kepercayaan konsumen dapat digunakan untuk mengukur sikap konsumen terhadap atribut produk kopi bubuk Kahyangan dibandingkan dengan Kapal Api Special, karena nilai koefisien validitas tiap atribut pertanyaan memiliki nilai $r$ hitung sesuai dengan tingkat signifikansi 0,01 sehingga dapat disimpulkan bahwa hubungan tiap atribut pertanyaan tersebut valid.

Pengujian reliabilitas pada perhitungan ini dilakukan dengan metode Alpha Cronbach. Jika diperoleh koefisien korelasi berada diatas koefisien reliabilitas yang telah ditetapkan yaitu sebesar 0,6 maka hubungan tersebut reliabel. Terlihat pada Tabel 1 bahwa semua atribut produk pada kuesioner penentuan evaluasi (evaluation) dan kepercayaan (believe) konsumen menunjukkan koefisien korelasi lebih besar dari 0,6 dengan demikian kuesioner tersebut dinyatakan reliabel. Berarti kuesioner tersebut mampu menunjukkan keakuratan, kestabilan dan konsistensi dalam menghasilkan data dari variabel yang diukur. 
Naning Retnowati, Alwan Abdurahman. Analisis Sikap Konsumen Pada Produk Kopi (Studi Kasus

Pada Perusahaan Pdp Kahyangan Kabupaten Jember )

Tabel 1.Hasil Uji Validitas dan Reliabilitas Kuesioner Penentuan Evaluasi (EValuation) dan KePercayaAn (BELIEVE) KONSUMEN TERHADAP ATRIBUT PRODUK KOPI

\begin{tabular}{|c|c|c|c|c|c|c|}
\hline & \multirow{2}{*}{ Penilaian } & \multirow{2}{*}{ Atribut } & \multicolumn{2}{|c|}{ Uji Validitas } & \multicolumn{2}{|c|}{ Uji Reliabilitas } \\
\hline & & & $\begin{array}{l}\text { r-hitung tingkat } \\
\text { sign. } 0,01\end{array}$ & $\begin{array}{c}\text { Keteran } \\
\text { gan }\end{array}$ & $\begin{array}{c}\text { Alpha } \\
\text { Cronbach }\end{array}$ & $\begin{array}{c}\text { Keteranga } \\
\text { n }\end{array}$ \\
\hline & \multirow{9}{*}{ 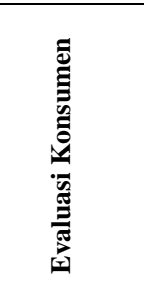 } & Warna Seduhan Kopi & 0,609 & Valid & \multirow{9}{*}{0,818} & \multirow{9}{*}{ Reliabel } \\
\hline & & Aroma Seduhan Kopi & 0,665 & Valid & & \\
\hline & & Rasa Seduhan Kopi & 0,685 & Valid & & \\
\hline & & Keasaman Seduhan Kopi & 0,717 & Valid & & \\
\hline & & Kekentalan Seduhan Kopi & 0,664 & Valid & & \\
\hline & & Kemasan & 0,697 & Valid & & \\
\hline & & Harga & 0,487 & Valid & & \\
\hline & & Ketersediaan Produk & 0,667 & Valid & & \\
\hline & & Informasi Produk & 0,630 & Valid & & \\
\hline \multirow{18}{*}{ 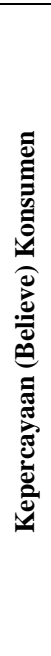 } & \multirow{9}{*}{ 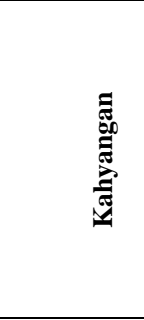 } & Warna Seduhan Kopi & 0,690 & Valid & \multirow{9}{*}{0,795} & \multirow{9}{*}{ Reliabel } \\
\hline & & Aroma Seduhan Kopi & 0,614 & Valid & & \\
\hline & & Rasa Seduhan Kopi & 0,589 & Valid & & \\
\hline & & Keasaman Seduhan Kopi & 0,739 & Valid & & \\
\hline & & Kekentalan Seduhan Kopi & 0,565 & Valid & & \\
\hline & & Kemasan & 0,547 & Valid & & \\
\hline & & Harga & 0,648 & Valid & & \\
\hline & & Ketersediaan Produk & 0,604 & Valid & & \\
\hline & & Informasi Produk & 0,552 & Valid & & \\
\hline & \multirow{9}{*}{ 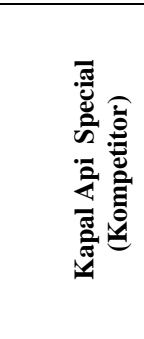 } & Warna Seduhan Kopi & 0,549 & Valid & \multirow{9}{*}{0,748} & \multirow{9}{*}{ Reliabel } \\
\hline & & Aroma Seduhan Kopi & 0,541 & Valid & & \\
\hline & & Rasa Seduhan Kopi & 0,596 & Valid & & \\
\hline & & Keasaman Seduhan Kopi & 0,561 & Valid & & \\
\hline & & Kekentalan Seduhan Kopi & 0,505 & Valid & & \\
\hline & & Kemasan & 0,621 & Valid & & \\
\hline & & Harga & 0,702 & Valid & & \\
\hline & & Ketersediaan Produk & 0,701 & Valid & & \\
\hline & & Informasi Produk & 0,662 & Valid & & \\
\hline
\end{tabular}

\subsection{Hasil Analisis}

\subsubsection{Atribut Produk Kopi}

Kopi merupakan jenis minuman penyegar yang nilainya tidak hanya ditentukan oleh penampilannya secara fisik, akan tetapi lebih ditentukan oleh cita rasanya. Cita rasa khas dari kopi ditambah dengan pengaruh fisiologis kafein dalam kopi yang menimbulkan rasa segar bagi yang mengkonsumsinya, menyebabkan kopi banyak diminati oleh masyarakat Indonesia. Hal penting bagi konsumen yang perlu diperhatikan dalam memilih produk kopi bubuk meliputi : (a) unsur organoleptik kopi, (b) kemasan produk; (c) harga produk, (d) ketersediaan produk dan (d) informasi produk. Unsur organoleptik kopi berkaitan dengan cita rasa kopi yang diinginkan dan diharapkan oleh konsumen, antara lain mencakup: (1) warna seduhan kopi, (2) aroma seduhan kopi, (3) rasa seduhan kopi, (4) keasaman, dan (5) kekentalan seduhan kopi.

Warna merupakan sifat fisik produk yang pertama kali dilihat oleh konsumen sebelum meminum kopi. Aroma merupakan sesuatu yang berkaitan dengan kesan yang dirasakan seseorang saat membau komponen volatil yang terlepas dari seduhan kopi dengan menggunakan indera pembaunya. Rasa merupakan sesuatu yang berkaitan dengan kesan yang dirasakan seseorang saat mencicipi seduhan kopi dengan bantuan indera pengecapnya. Keasaman merupakan kesan cita rasa yang berkaitan dengan senyawa asam pada seduhan kopi. Kekentalan (body) merupakan ciri-ciri fisik dari seduhan kopi yang menimbulkan kesan penuh selama dan setelah mengkonsumsi kopi (Ismayadi, 2007).

Unsur (atribut whats) lainnya yang juga penting dan melekat pada produk kopi bubuk adalah kemasannya. Kemasan yang baik bagi konsumen adalah kemasan dengan kualitas bahan baku yang baik, memiliki desain yang menarik, seal kemasan yang rapat sehingga tidak mudah bocor, dan pencantuman batas waktu tanggal kadaluarsa. Jenis bahan dan seal kemasan yang baik sangatlah penting karena kopi bubuk bersifat higroskopis sehingga mudah mengalami penurunan kualitas.

Unsur lain yang penting bagi konsumen adalah harga produk. Pada saat ini dengan daya 
beli mayoritas konsumen yang semakin rendah, penetapan harga menjadi hal yang sangat penting karena konsumen akan menjadi lebih kritis dan selektif dalam membeli suatu produk. Harga produk yang bersaing dengan produk kompetitor dan sesuai dengan kualitas produk kopi bubuk, menyebabkan konsumen menjadi loyal.

Ketersediaan produk di pasaran merupakan hal yang penting bagi konsumen. Saat ini produk yang mudah diperoleh konsumen/banyak tersedia di pasar akan lebih banyak dibeli oleh konsumen, maka dari itu perusahaan/produsen harus mampu memasarkan produknya secara luas di setiap pasar sampai pada niche/relung market (Tandjung, 2004).

Informasi produk saat ini juga merupakan hal yang penting bagi konsumen. Menurut pendapat Lubis (2004), suatu produk tidak akan dibeli bahkan dikenal apabila konsumen tidak mengetahui kegunaan, keunggulan, harga dan dimana produk dapat diperoleh dan berapa harganya. Untuk itulah konsumen yang menjadi sasaran produk atau jasa perusahaan perlu diberikan informasi yang jelas. Penyebaran informasi produk kepada konsumen dilakukan dengan promosi/iklan.

\subsubsection{Analisis Evaluasi (Evaluation) Konsumen Terhadap Atribut Produk Kopi}

Evaluasi konsumen $\left(\mathbf{e}_{\mathbf{i}}\right)$ berisi penilaian konsumen terhadap masing-masing atribut kualitas produk kopi dalam memenuhi kebutuhannya.

Hasil evaluasi atribut yang dinilai oleh konsumen terhadap produk kopi, secara keseluruhan menunjukkan bahwa semua atribut dinilai penting atau positif oleh konsumen. Tingkat kepentingan yang dinilai konsumen berbeda-beda menurut besarnya skor evaluasi yang diperoleh. Semakin tinggi skor evaluasi yang diperoleh maka semakin penting suatu atribut. Hasil evaluasi konsumen terhadap atribut produk kopi dapat dilihat pada Tabel 2.

TABel 2. Nilai Evaluasi TerhadAP Atribut KoPI BUBUK

\begin{tabular}{|c|l|c|c|}
\hline No. & \multicolumn{1}{|c|}{ Atribut } & $\begin{array}{c}\text { Skor } \\
\text { Evalua } \\
\left.\text { si (e } \mathbf{e}_{\mathrm{i}}\right) / \\
\text { Kepenti } \\
\text { ngan }\end{array}$ & $\begin{array}{c}\text { Kategori } \\
\text { Tingkat } \\
\text { Kepentingan }\end{array}$ \\
\hline 1 & Warna Seduhan Kopi & 4,11 & Penting \\
\hline 2 & Aroma Seduhan Kopi & 4,69 & Sangat Penting \\
\hline 3 & Rasa Seduhan Kopi & 4,90 & Sangat Penting \\
\hline 4 & Keasaman Seduhan Kopi & 4,23 & Sangat Penting \\
\hline 5 & Kekentalan Seduhan Kopi & 4,16 & Penting \\
\hline 6 & Kemasan & 4,01 & Penting \\
\hline 7 & Harga & 3,60 & Penting \\
\hline
\end{tabular}

\begin{tabular}{|l|l|c|c|}
\hline 8 & Ketersediaan Produk & 4,13 & Penting \\
\hline 9 & Informasi Produk & 4,10 & Penting \\
\hline
\end{tabular}

Dari tabel di atas terlihat bahwa atribut aroma, rasa, dan keasaman seduhan kopi adalah tiga atribut yang dianggap sangat penting bagi konsumen dalam mempertimbangkan pembelian produk kopi. Atribut yang dianggap penting meliputi warna seduhan kopi, kekentalan seduhan kopi, kemasan, harga, ketersediaan produk, dan informasi produk.

Rasa seduhan kopi merupakan unsur organoleptik kopi yang menjadi prioritas pertama bagi konsumen. Kopi dengan cita rasa yang nikmat dan sesuai dengan selera konsumen akan memberikan kepuasan bagi konsumen dan selanjutnya konsumen akan kembali untuk membeli produk yang sama. Rasa seduhan kopi yang disukai konsumen adalah yang memiliki flavor (rasa) kopi yang kuat dan berasa coklat (chocolaty).

Aroma seduhan kopi menjadi prioritas kedua bagi konsumen setelah rasa seduhan kopi. Aroma seduhan kopi yang umumnya disukai oleh konsumen adalah dengan aroma buah-buahan (fruity), aroma tumbuh-tumbuhan (floral) dan beraroma coklat (chocolaty). Unsur organoleptik rasa dan aroma kopi ini saling berkaitan, kopi dengan aroma dan rasa yang nikmat akan dapat memberikan kepuasan bagi konsumen sehingga pada akhirnya konsumen akan berkeinginan untuk kembali mengkonsumsi produk yang sama.

Prioritas tingkat kepentingan yang ketiga adalah keasaman kopi, merupakan hal yang penting karena berkaitan dengan tingkat kesukaan dan kesehatan konsumen. Kopi dengan tingkat keasaman yang tinggi kurang disukai oleh konsumen karena dapat mempengaruhi kesehatan lambung konsumen kopi. Robusta merupakan jenis kopi yang memiliki tingkat keasaman yang cukup rendah dibandingkan kopi arabika.

Prioritas keempat adalah kekentalan seduhan kopi, merupakan unsur organoleptik yang cukup diutamakan oleh konsumen. Produk kopi yang memiliki tingkat kekentalan yang cukup tinggi sangat disukai konsumen dan hal ini berkaitan pula dengan aspek cita rasa. Kopi yang memiliki tingkat kekentalan yang rendah pada umumnya memiliki rasa yang hambar karena partikel kopi pembentuk cita rasa kopi (gula sederhana, asam-asam organik, asam lemak) yang terlarut dalam air seduhan hanya sedikit (Yusianto, 2004). 
Naning Retnowati, Alwan Abdurahman. Analisis Sikap Konsumen Pada Produk Kopi (Studi Kasus

Pada Perusahaan Pdp Kahyangan Kabupaten Jember )

Selanjutnya urutan prioritas kelima adalah ketersediaan produk, konsumen akan lebih memilih produk yang banyak tersedia di pasar. Saat ini banyak konsumen yang mengutamakan hal kepraktisan dan kemudahan dalam memperoleh produk. Produk yang banyak tersedia di pasar juga dapat menyebabkan konsumen menjadi loyal. Menurut Tandjung (2004), salah satu cara yang dapat dilakukan perusahaan untuk meningkatkan nilai pelanggan (value) adalah dengan memberi kemudahan konsumen untuk memperoleh produk dengan cara memperluas daerah pendistribusian produk.

Urutan prioritas keenam adalah warna seduhan kopi, unsur organoleptik ini sedikit terabaikan karena setiap produk kopi bubuk memiliki banyak kesamaan berkaitan dengan intensitas warna seduhan kopi. Warna seduhan kopi yang umumnya disukai oleh masyarakat Indonesia adalah coklat tua.

Urutan prioritas ketujuh adalah informasi produk. Pada era informasi yang semakin modern konsumen umumnya lebih memilih produk yang banyak menampilkan iklan produknya terutama pada media elektronik. Dengan informasi produk berupa iklan akan menimbulkan ketertarikan konsumen untuk membeli suatu produk (Lubis, 2004).

Urutan prioritas kepentingan yang kedelapan adalah kemasan produk, bagi konsumen pencinta kopi, kemasan produk tidak terlalu penting karena yang paling penting adalah kualitas produk kopi bubuk. Kemasan yang menarik tanpa didukung oleh kualitas produk yang baik hanya akan menimbulkan ketertarikan sementara pada konsumen. Pada akhirnya setelah konsumen mengetahui bahwa citarasa produk tersebut tidak sesuai dengan keinginan dan harapannya maka konsumen akan beralih ke produk lain yang kualitasnya lebih baik, walaupun kemasan produk tersebut kurang menarik (Tandjung, 2004).

Urutan prioritas terakhir adalah harga produk, bagi pencinta kopi harga produk bukanlah hal yang penting karena yang terpenting adalah rasa dan aroma dari produk kopi. Saat ini konsumen lebih selektif dalam memilih produk, suatu perusahaan kopi bubuk yang menawarkan harga yang lebih rendah tanpa didukung kualitas produk yang baik belum tentu dapat mempengaruhi loyalitas konsumen terhadap suatu produk (Dianawati et. al, 2000). Akan tetapi kondisi ini akan berbeda jika perusahaan tersebut selain menawarkan harga yang kompetitif juga menawarkan produk dengan kualitas yang baik.

\subsubsection{Analisis Kepercayaan (Believe) Konsumen Terhadap Atribut Produk Kopi Bubuk Kahyangan Dibandingkan Kompetitor}

Tingkat kepercayaan (believe) dengan simbol $\mathbf{b}_{\mathbf{i}}$ menunjukkan penilaian konsumen terhadap pelaksanaan atribut produk. Penilaian kepercayaan konsumen mengenai seberapa baik kualitas produk kopi bubuk Kahyangan ditunjukkan pada Tabel 3.

Tabel 3. Nilai KePercayaAn Terhadap Atribut KOPI BUBUK KAHYANGAN

\begin{tabular}{|c|l|c|c|}
\hline No & \multicolumn{1}{|c|}{ Atribut } & $\begin{array}{c}\text { Skor } \\
\text { Kepercaya } \\
\text { an }\left(\mathbf{b}_{\mathbf{i}}\right)\end{array}$ & $\begin{array}{c}\text { Kategori } \\
\text { Tingkat } \\
\text { Kepercayaan }\end{array}$ \\
\hline 1 & Warna Seduhan Kopi & 3,86 & Baik \\
\hline 2 & Aroma Seduhan Kopi & 4,31 & Sangat Baik \\
\hline 3 & Rasa Seduhan Kopi & 4,70 & Sangat Baik \\
\hline 4 & Keasaman Seduhan Kopi & 3,80 & Baik \\
\hline 5 & Kekentalan Seduhan Kopi & 3,93 & Baik \\
\hline 6 & Kemasan & 3,22 & Cukup Baik \\
\hline 7 & Harga & 4,21 & Sangat Baik \\
\hline 8 & Ketersediaan Produk & 2,26 & Kurang Baik \\
\hline 9 & Informasi Produk & 2,34 & Kurang Baik \\
\hline
\end{tabular}

Berdasarkan Tabel 3 tampak bahwa penilaian kepercayaan konsumen terhadap atribut aroma, rasa seduhan kopi dan harga kopi bubuk Kahyangan adalah sangat baik. Penilaian kepercayaan konsumen terhadap atribut warna, keasaman, dan kekentalan seduhan kopi adalah baik. Penilaian konsumen terhadap kemasan produk adalah cukup baik. Sedangkan penilaian konsumen terhadap atribut ketersediaan dan informasi produk dinilai kurang baik.

Konsumen menilai aroma dan rasa seduhan kopi bubuk Kahyangan sangat enak dan sesuai dengan keinginan dan kebutuhan konsumen. Harga produk dinilai sangat baik karena harga produk yang bersaing dibandingkan dengan produk kompetitor (Kapal Api Special). Warna, keasaman dan kekentalan seduhan kopi bubuk Kahyangan dinilai baik oleh konsumen karena sesuai dengan kriteria konsumen. Kemasan produk dinilai cukup baik oleh konsumen karena perpaduan desain dan bahan kemasan produk cukup sesuai dengan harapan. Ketersediaan dan informasi produk kopi bubuk Kahyangan dinilai kurang baik karena merk ini kurang dikenal oleh konsumen dan produk hanya tersedia di beberapa outlet toko sehingga kurang bisa terjangkau oleh konsumen.

Penilaian kepercayaan konsumen mengenai seberapa baik kualitas produk kopi bubuk Kapal Api Special ditunjukkan pada Tabel 4. 
Tabel 4. Nilai KePercayaAn Terhadap Atribut KOPI BUBUK KAPAL API SPECIAL

\begin{tabular}{|c|l|c|c|}
\hline No & \multicolumn{1}{|c|}{ Atribut } & $\begin{array}{c}\text { Skor } \\
\text { Kepercaya } \\
\text { an }\left(\mathbf{b}_{\mathbf{i}}\right)\end{array}$ & $\begin{array}{c}\text { Kategori } \\
\text { Tingkat } \\
\text { Kepercayaan }\end{array}$ \\
\hline 1 & Warna Seduhan Kopi & 3,91 & Baik \\
\hline 2 & Aroma Seduhan Kopi & 4,58 & Sangat Baik \\
\hline 3 & Rasa Seduhan Kopi & 4,64 & Sangat Baik \\
\hline 4 & Keasaman Seduhan Kopi & 3,88 & Baik \\
\hline 5 & Kekentalan Seduhan Kopi & 3,91 & Baik \\
\hline 6 & Kemasan & 4,21 & Sangat Baik \\
\hline 7 & Harga & 4,15 & Baik \\
\hline 8 & Ketersediaan Produk & 4,76 & Sangat Baik \\
\hline 9 & Informasi Produk & 4,49 & Sangat Baik \\
\hline
\end{tabular}

Berdasarkan Tabel 4 tampak bahwa penilaian kepercayaan konsumen terhadap atribut aroma, rasa seduhan kopi, kemasan, ketersediaan dan informasi produk kopi bubuk Kapal Api Special adalah sangat baik. Penilaian kepercayaan konsumen terhadap atribut warna, keasaman, kekentalan seduhan kopi, dan harga produk adalah baik.

Berdasarkan Tabel 3 dan Tabel 4 tampak bahwa penilaian kepercayaan konsumen terhadap atribut rasa dan aroma seduhan kopi di kedua produsen sama-sama memiliki penilaian dengan kategori sangat baik, menunjukkan bahwa PDP Kahyangan dan PT. Santos Jaya Abadi telah mampu menciptakan produk kopi bubuk yang sesuai dengan keinginan konsumen. Pada atribut harga produk kopi bubuk Kahyangan lebih unggul dibandingkan Kapal Api Special. Harga produk kopi bubuk Kahyangan dinilai konsumen lebih ekonomis (bersaing) bila dibandingkan produk Kapal Api Special.

Analisis perbandingan antara nilai kepercayaan (believe) konsumen pada Kopi PDP Kahyangan dengan nilai evaluasi terhadap atribut produk tampak bahwa produsen telah mampu memenuhi keinginan konsumen dalam hal rasa, dan aroma dengan nilai yang sangat baik. Rasa dan aroma seduhan kopi merupakan atribut yang menjadi prioritas konsumen dalam membeli produk kopi bubuk. Pada atribut keasaman yang menjadi prioritas konsumen dalam membeli produk, kopi bubuk Kahyangan dan Kapal Api Special mendapatkan penilaian baik dari konsumen. Penilaian konsumen terhadap atribut harga produk, kopi bubuk Kahyangan juga memberikan nilai sangat baik. Hal ini menunjukkan bahwa kopi bubuk Kahyangan memiliki keunggulan dalam hal harga dibandingkan Kapal Api Special. Akan tetapi pada atribut kemasan, ketersediaan dan informasi produk, Kapal Api Special dinilai konsumen lebih unggul dibandingkan kopi bubuk Kahyangan. Bahan serta desain kemasan Kapal Api Special dinilai lebih baik dan menarik. Ketersediaan produk Kapal Api Special juga jauh lebih baik karena proses distribusi produk sangat baik. Konsumen juga banyak mengenal produk Kapal Api Special dari promosi produk yang disampaikan melalui media cetak dan elektronik.

\subsubsection{Analisis Sikap Konsumen Terhadap Atribut Produk Kopi Bubuk Kahyangan Dibandingkan Kompetitor}

Analisis sikap konsumen $\left(\mathbf{A}_{\mathbf{o}}\right)$ dapat dilakukan setelah penilaian terhadap evaluasi atribut produk dan penilaian kepercayaan produk selesai dilakukan. Sikap konsumen terhadap atribut produk kopi bubuk Kahyangan dibandingkan dengan kopi Kapal Api Special ditunjukkan pada Tabel 5.

Tabel 5. Nilai Sikap Konsumen Terhadap Atribut Produk Kopi Bubuk Kahyangan dan KaPal Api Special

\begin{tabular}{|c|c|c|c|c|c|c|c|c|}
\hline \multirow[b]{2}{*}{ No. } & \multirow[b]{2}{*}{ Atribut } & \multirow[b]{2}{*}{$\begin{array}{c}\text { Skor } \\
\mathbf{e}_{\mathbf{i}}\end{array}$} & \multicolumn{3}{|c|}{ Kahyangan } & \multicolumn{3}{|c|}{ Kapal Api Special } \\
\hline & & & $\mathbf{b}_{\mathbf{i}}$ & $\begin{array}{c}A_{0}=e_{i} . \\
b_{i}\end{array}$ & $\begin{array}{c}\text { Kategori } \\
\text { Sikap }\end{array}$ & $\mathbf{b}_{\mathbf{i}}$ & $\begin{array}{c}\mathbf{A}_{\mathbf{0}}=\mathrm{e}_{\mathrm{i}} . \\
\mathbf{b}_{\mathbf{i}}\end{array}$ & $\begin{array}{c}\text { Kategori } \\
\text { Sikap }\end{array}$ \\
\hline 1 & Warna Seduhan Kopi & 4,11 & 3,86 & 15,86 & Positif & 3,91 & 16,07 & Positif \\
\hline 2 & Aroma Seduhan Kopi & 4,69 & 4,31 & 20,21 & Sangat Positif & 4,58 & 21,48 & Sangat Positif \\
\hline 3 & Rasa Seduhan Kopi & 4,90 & 4,70 & 23,03 & Sangat Positif & 4,64 & 22,74 & Sangat Positif \\
\hline 4 & $\begin{array}{l}\text { Keasaman Seduhan } \\
\text { Kopi }\end{array}$ & 4,23 & 3,80 & 16,07 & Positif & 3,88 & 16,41 & Positif \\
\hline 5 & $\begin{array}{l}\text { Kekentalan Seduhan } \\
\text { Kopi }\end{array}$ & 4,16 & 3,93 & 16,35 & Positif & 3,91 & 16,27 & Positif \\
\hline 6 & Kemasan & 4,01 & 3,22 & 12,91 & Netral & 4,21 & 16,88 & Positif \\
\hline 7 & Harga & 3,60 & 4,21 & 15,16 & Netral & 4,15 & 14,94 & Netral \\
\hline 8 & Ketersediaan Produk & 4,13 & 2,26 & 9,33 & Negatif & 4,76 & 19,66 & Positif \\
\hline 9 & Informasi Produk & 4,10 & 2,34 & 9,59 & Negatif & 4,49 & 18,41 & Positif \\
\hline & $\sum \mathbf{e}_{\mathbf{i}} \cdot \mathbf{b}_{\mathbf{i}}$ & & & $\begin{array}{c}138,5 \\
3\end{array}$ & Positif & & $\begin{array}{c}162,8 \\
5\end{array}$ & Positif \\
\hline
\end{tabular}


Naning Retnowati, Alwan Abdurahman. Analisis Sikap Konsumen Pada Produk Kopi (Studi Kasus

Pada Perusahaan Pdp Kahyangan Kabupaten Jember )

Sikap konsumen pada atribut warna, keasaman, dan kekentalan seduhan kopi kedua produk (kopi bubuk Kahyangan dan Kapal Api Special) bernilai positif menunjukkan bahwa kinerja ketiga atribut tersebut telah dinilai baik oleh konsumen. Atribut kemasan dan harga pada produk kopi bubuk Kahyangan mendapat respon netral, sedangkan atribut ketersediaan dan informasi produk mendapatkan respon negatif. Sikap negatif dapat menghalangi konsumen dalam melakukan pembelian produk. Maka dari itu PDP Kahyangan harus dapat memperbaiki cara penentuan harga, desain dan bahan kemasan produk, cara distribusi produk dan promosi produknya agar respon konsumen menjadi positif pada keempat atribut tersebut.

Pada produk Kapal Api Special, atribut kemasan, ketersediaan dan informasi produk mendapat respon positif, sedangkan atribut yang mendapat respon netral hanya atribut harga. Hal ini menunjukkan bahwa menurut konsumen kinerja atribut kemasan, ketersediaan, dan informasi produk pada Kapal Api Special lebih baik dibandingkan kopi bubuk Kahyangan.

Pada Tabel 5 bagian jumlah sikap keseluruhan atribut juga terlihat bahwa sikap konsumen pada produk kopi bubuk Kahyangan dan Kapal Api Special sama-sama menunjukkan respon yang baik (positif), walaupun skor total sikap konsumen produk Kapal Api Special sedikit lebih tinggi dibandingkan kopi bubuk Kahyangan.

\section{KESIMPULAN DAN SARAN \\ 4.1 Kesimpulan}

a) Kriteria atribut produk kopi yang diinginkan dan dibutuhkan konsumen konsumen meliputi sembilan (9) atribut, dengan urutan prioritas tingkat kepentingan sebagai berikut : rasa, aroma, keasaman, kekentalan seduhan kopi, ketersediaan produk, warna seduhan kopi, informasi produk, kemasan produk, dan harga produk

b) Sikap konsumen pada atribut rasa dan aroma seduhan produk kopi Kahyangan dan Kapal Api Special sangat positif. Atribut rasa produk kopi bubuk Kahyangan dibandingkan Kapal Api Special memiliki nilai yang lebih tinggi, $(23,03)$. Jumlah total skor sikap konsumen pada produk kopi bubuk Kahyangan $(138,53)$ sedikit lebih rendah dibandingkan kopi Kapal Api Special $(162,85)$ dengan respon keduanya positif. Hal tersebut menunjukkan bahwa penerimaan konsumen terhadap produk kopi bubuk Kahyangan dan Kapal Api Special adalah baik (positif).

\subsection{Saran}

Berdasarkan hasil penelitian diketahui bahwa atribut rasa, aroma dan keasaman seduhan kopi menjadi pertimbangan utama konsumen dalam keputusan pembelian produk. Maka dari itu, produsen kopi bubuk PDP Kahyangan harus bisa meningkatkan kualitas produknya, misal dengan senantiasa melakukan perbaikan pada proses produksinya. Atribut produk lainnya yang harus dilakukan upaya perbaikan adalah kemasan, harga, ketersediaan dan informasi produk.

\section{DAFTAR PUSTAKA}

[1] Dharmmesta, Basu Swastha. 1997. Keputusan Keputusan Strategik untuk Mengeksplorasi Sikap dan Perilaku Konsumen. Jurnal Ekonomi dan Bisnis Indonesia, 12 (3): 1-19

[2] Dianawati, W, P. Yulianti, dan N. Herachwati. 2000. Analisis Perilaku Konsumen Dalam Pengambilan Keputusan Pembelian Makanan Pada Waralaba Pangan. Jurnal Penelitian Din. Sos. Vol. I (3). Hal. 74-81.

[3] Ismayadi, Cahya. 2007. Karakteristik dan Deskripsi Citarasa Kopi. Materi Pelatihan Uji Pelatihan Citarasa Kopi. Pusat Penelitian Kopi dan Kakao Indonesia. Jember

[4] Kristianto, Paulus Lilik. 2011. Psikologi Pemasaran : Integrasi Ilmu Psikologi dalam Kegiatan Pemasaran. CAPS. Jakarta

[5] Lubis, Arlina Nurbaity. 2004. Peran Distribusi. Fakultas Ekonomi Universitas Sumatera Utara. Medan

[6] Schiffman, Leon dan Leslie Lazar Kanuk. 2004. Perilaku Konsumen. Penerbit Indeks. Jakarta

[7] Sekaran, Uma. 2000. Research Methods For Business: A Skill-Building Approach, 3rd ed. John Wiley \& Sons: Inc.

[8] Simamora, Bilson. 2002. Panduan Riset Perilaku Konsumen. Gramedia. Jakarta

[9] Tandjung, J.W. 2004. Marketing Management. Pendekatan Pada Nilai-nilai Pelanggan. Bayu Media. Malang

[10] Yusianto dan Sri Mulato. 2007. Pengolahan dan Komposisi Kimia Biji Kopi : Pengaruhnya Terhadap Citarasa Seduhan. Materi Pelatihan Uji Pelatihan Citarasa Kopi. Pusat Penelitian Kopi dan Kakao Indonesia. Jember 